\title{
Translation Techniques of Traditional Karonese Medical Text on Fractured Bone Setting
}

\author{
Herlina Surbakti, M.A., Prof. T. Silvana Sinar, Ph.D., \\ Dr. Syahron Lubis, M.A., Dr. Muhizar Muchtar, M.S. \\ Linguistic Department, University of Sumatera Utara (USU), Medan, North Sumatra, Indonesia
}

\begin{abstract}
The majority of bone injuries in North Sumatra are treated by traditional bone setters. Documentation of traditional bone setting is rare, if existent at all. To preserve this knowledge, authentic written records of Karonese medical knowledge should be made available to Karonese and all Indonesian society. This study is entitled "Translation Techniques of Traditional Karonese Medical Text on Fractured Bone Setting”. Qualitative research method was used to collect and analyze the data. Interviews were conducted with four bonesetters and two herbalists. From 188 data sources analyzed, 152 were decoded by applying single 44 couplets and 2 triplet techniques. The translation techniques from the Karonese language to English are literal (99), pure borrowing (62), established equivalent (10), calque (2), with a total of $183=71 \%$. Also, target language emphasis data used are: addition (38), deletion (9), transposition (21), and adaptation (3) with total $71=29 \%$. Therefore, the technique of translation using the most literal equivalent of the source language (71\%) is not only feasible but also necessary so that the original Karonese medical terms can be faithfully preserved in the translation.
\end{abstract}

Keywords: Karonese traditional medicine, translation technique, fractured bone setting

\section{Introduction}

Globalization has caused an increase of mobility and a growing relationship between the world communities of speakers of many languages. As a result, translation has become a more critical tool to improve cross-cultural understanding to ensure economic prosperity among countries. English is currently the language in which most communication is now taking place worldwide. It has become almost a necessity for people to speak English if they are to enter a global workforce and interact with professionals throughout the world.

While speaking the same language has a multitude of benefits, there is a concern that languages which have relatively small numbers of speakers will be threatened. After many years when only Bahasa Indonesia was spoken at home and at school, many Indonesians of various ethnic groups have lost their cultural identities/values. Charles Darwin in The Origin of Species stated that a species can survive and pass through a series of challenges and violent nature if the species is able to adapt to change. It is not the stronger molecular

\footnotetext{
Herlina Surbakti, M.A., Ph.D. student, Linguistic Department, University of Sumatera Utara (USU). (Email: hsurbakti@gmail.com.)

Prof. T. Silvana Sinar, lecturer, Ph.D., Linguistic Department, University of Sumatera Utara (USU). (Email: tengkusilvana@usu.ac.id.)

Dr. Syahron Lubis, lecturer, M.A., Linguistic Department, University of Sumatera Utara (USU). (Email: ronlubis@gmail.com.)

Dr. Muhizar Muchtar, lecturer, M.S., Linguistic Department, University of Sumatera Utara (USU). (Email: muhizarm@yahoo.com.)
} 
makeup that will cause it to survive, but rather its ability to adjust to changes, i.e., climate, famine, drought, etc. Those creatures that have a natural intelligence and flexibility to respond to changing circumstances will survive; others will become extinct. With more than 300 native languages and multiple ethnic groups in Indonesia, Bahasa has an important unifying influence on the country. Nasution (2014) stated:

Language shift in using the local language by the young generation happened because the parents failed to transfer their native languages to their children. The local language was forgotten because of the need to study Bahasa Indonesia and English in school. Negative stigma attached to the local language made the younger generation forget their native language. They don't want to be old fashioned. (p. 296)

This phenomenon is especially true in North Sumatra where Karo youth are no longer interested in speaking their native language and there is a fear that Karonese will eventually become extinct. Should this occur, Karo oral traditions and other inherited knowledge would also disappear. While documentation does not necessarily ensure that a language will survive, specific knowledge can be passed on from one generation to another through translation. With this study, Karonese oral tradition regarding the healing of fractures has been translated and recorded. By reviewing and studying the translation techniques in the tradition of one aspect of Karonese tradition and culture to preserve it in some way. In this case, the study focuses on "Translation Techniques of Traditional Karonese Medical Text on Fractured Bone Setting".

Setting bone fractures in North Sumatra is done by a healer, or "Guru Pertawar Penggel", through the use of different kinds of traditional medicines. Medicinal oils known as "minakpengalun", "sembur", and "tawar" are made specially by the healer from indigenous plants found in the region. These highly concentrated oils are used in the treatment of sprains, bone shifts, bruises, fractures, and other bone and muscles related traumas. The traditional healer, "Guru Pertawar Penggel", only sees to the bone or muscles that are problematic, then sets it to the normal position using his/her touch alone. The bone setter uses the special oils made by the healer $\mathrm{him} /$ herself and then props up the injured arm or leg with a buffer made of bamboo or wood. The patient is sent home with traditional herbal medicines such as tawar, minak, and kompres.

While the primary focus of this study is emphasis on translation techniques, the outcome has a number of benefits. As advanced medical technology becomes more prevalent, this study raises the issue of traditional medicine as a credible alternative. It also places importance on the need to protect natural resources, particularly medicinal plants that benefit local populations. For other researchers in traditional medicine, especially in the treatment of bone fractures with herbal oil, this subject might be of interest for further study. One of the objectives of this study after having documented, described, and analyzed the traditional bone and muscle treatments is to introduce it to Indonesian health sector as well as to the international community, including the World Health Organization. The problem of this research is formulated as "What techniques of translation are used in translating the traditional Karonese medical text on fractured bone setting?". The objective of this study is to describe the techniques that were adopted in translating the traditional Karonese medical text on fractured bone setting.

\section{Review of Related Literature}

A professional translator is required to have linguistic mastery of both the source language and target language. It is not just being able to speak both languages, but s/he should be able to detect the differences and similarities between the two linguistic features of the language. Hatim and Munday (2009) wrote that translation is a multi-disciplinary discipline and it requires the contribution of various sub-disciplines of 
linguistics such as semantics, sociolinguistics, pragmatics, analysis discourse, contrastive linguistics, cognitive linguistics, and other disciplines such as philosophy, language engineering, cultural studies, and literature.

Thus, translation should not be based only on one theory; rather, it should be based on a number of theories (eclectic) that are mutually related and supportive of each other. This type of translation corresponds to "interlingual translation". The word "translation" has several meanings. It can be referred to as a general subject field: A product or a text that has been translated or the process of the act of producing the translation. The process of translation between two different languages involves the translator changing an original or the source text (ST) into the target text (TT).

Initially, translation was regarded as an operating language alone. However, language is part of culture that is closely related to the way of thinking, so that a particular cultural community will have its own way of thinking through language. Therefore, when one studies a foreign language, one will also automatically learn the related culture. The most fundamental relationship of language and culture is that the language should be studied in the context of culture and culture can be learned through language learning. Different cultures will produce different words because every culture has a different concept. Therefore, translating is not limited to cross-language transfer but on cross-cultural transfer as well.

When the translator starts from the highest level, the text, and continues to a lower level, then the translator is applying the top-down approach (see Baker, 1992, p. 6; Hervey, Higgins, \& Haywood, 1995, p. 1). Procedures and measures in the top-down approach are illustrated through the triangle (see Figure 1).

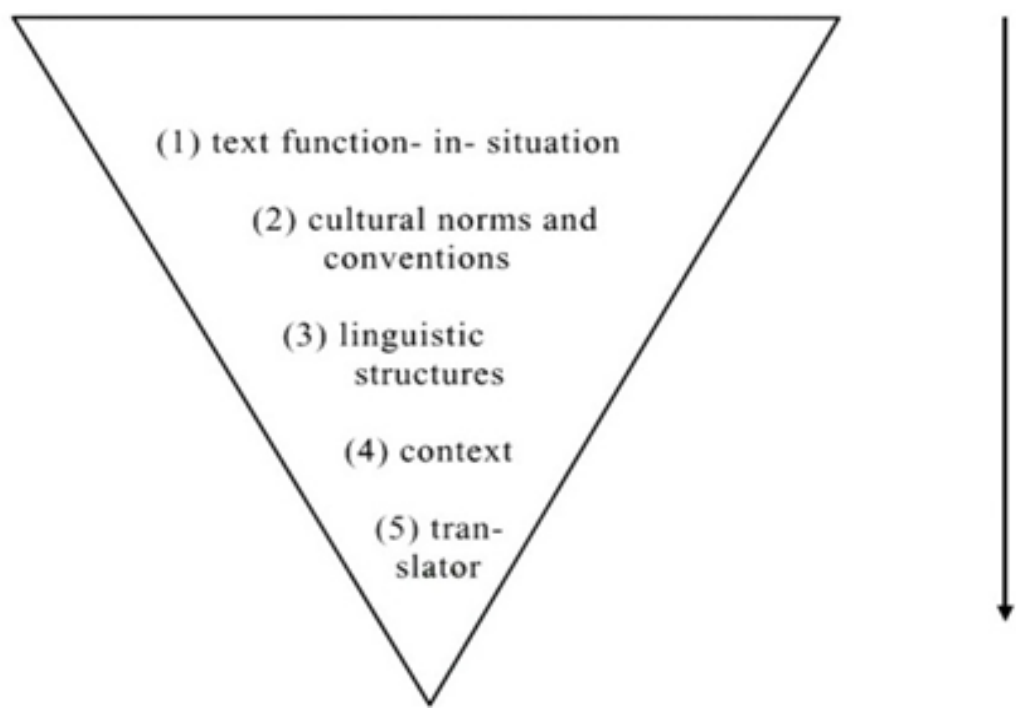

Figure 1. Top-down approach translation.

Molina and Albir (2002) define a translation technique as a procedure to analyze and classify how equivalent translation in progress can be applied to various lingual units. They defined seven basic procedures operating on three levels of style: lexis, distribution (morphology and syntax), and message. The procedures were classified as direct or literal or oblique, to coincide with their distinction between direct or literal and oblique translation. Literal translation occurs when there is an exact structural, lexical, even morphological equivalence between two languages. According to the authors, this is only possible when the two languages structures are close to each other.

The literal translation procedures are: (1) borrowing; (2) calque; and (3) literal translation. 
Oblique translation occurs when word for word translation is impossible. The oblique translation procedures are: (1) transposition; (2) modulation; (3) equivalence; (4) adaptation (a shift in cultural environment); (5) compensation (an item of information, or a stylistic effect from the ST); (6) concentration versus dissolution; (7) amplification versus economy; (8) reinforcement versus condensation; (9) explicitation versus implicitation; (10) generalization versus particularization; and (11) inversion.

\section{Methodology}

\section{Design}

The research commenced by interviewing four bone setters and two herbalists. Two assistants worked in the field to collect $209-11=183$ of the data source. These data sources were analyzed: They were identified 152 data were translated using Single Techniques; 44 data were translated using Couplets; and 2 data were translated with triplet techniques.

This study used qualitative research method because the researcher wanted in-depth understanding of a situation or issue, so that it became important to test the unknown variables that can affect a particular phenomenon. There are several kinds of descriptive qualitative research methods and the ones which are compatible with the first part of this study, they are: (1) ethnography, which involves a field-based study lengthy enough to surface people's everyday norms, rituals, and routines in detail and (2) participant-observer study where the researcher conducts field-based research based on the researcher locating in the real-world setting being studied (Yin, 2011).

\section{Place and Time of the Research}

The location of this research is spread in different parts of North Sumatra, i.e., in the Karo highlands and the lowlands that are in Deli Serdang, Langkat, and Southeast Aceh Districts. Three of the Guru Pertawar Penggel live in the highlands and two herbalists live in Deli Serdang. An assistant, Eddy Ginting, is familiar with herbs that come from districts Berastagi to look for herbs in the rainforest. It is recommended to have multiple sources of evidence rather than relying on a single source alone, Yin (2011) data collection began in January 2015 and completed in June 2015.

\section{Data and Data Sources}

The main data sources of this study were narrative texts describing oral traditions of Karo society regarding treatment of bone fractures. These narrative texts were recorded using a tape recorder. Included in the data were interviews with four "Guru Pertawar Penggel" or practitioners of traditional Karonese bone setters, interviews with people who are familiar with the herbal plants of the rainforest in North Sumatra and providers of traditional Karonese medicines. The data were words, phrases, and sentences that included 60 herbal terms in Karonese which were translated into English. Among the herbs used in this study there were 28 herbs which equivalent names could not be found; therefore, they were untranslatable from Karonese into English.

\section{Data Collection Techniques}

The researcher collected data through individual interviews, both open interview formats and semi-standard or semi-structured formats. Berg (2009) asserts that a semi-standard interview involves asking a number of questions that have researchers approach the world from the perspective of the subject. Semi-structured interview is flexible. This allows the interviewer to ask a series of structures questions, allowing for comparisons during the interview, but also allows the interviewer to ask questions spontaneously. 
By frequency of use in the whole data of this study, it is known that the literal technique tops (99), followed by pure borrowing technique (62), addition technique (38), transposition technique (21), established equivalent (10), deletion technique (9) adaptation technique (3), calque technique (2) in theory, of eight translation techniques above, four translation techniques, they are literal techniques, established equivalent, borrowing technique and calque, oriented to the language and culture of the source language. While four other translation techniques, they are the addition techniques, the deletion techniques, transposition techniques, adaptation techniques oriented around the target language and culture (see Table 1).

Table 1

Frequency of Use in the Whole Data

\begin{tabular}{llllll}
\hline & & \multicolumn{4}{c}{ Technique variation } \\
\cline { 3 - 6 } No. & Technique & Single & Couplet & Triplet & Total \\
\hline 1. & Literal & 66 & 32 & 1 & 99 \\
2. & Pure borrowing & 23 & 37 & 2 & 62 \\
3. & Established equivalent & 9 & 1 & - & 10 \\
4. & Calque & - & 1 & 1 & 2 \\
5. & Addition & 29 & 7 & 2 & 38 \\
6. & Deletion & 7 & 2 & - & 9 \\
7. & Transposition & 17 & 4 & - & 21 \\
8. & Adaptation & 1 & 2 & & 3 \\
\end{tabular}

\section{Data Analysis and Findings}

Collecting data and analyzing results involved five basic activities. The first activity involved observing every day norms, rituals, and routines, and interviewing four Karonese bone setters.

During the interviews, the bone setters recommended interviewing two herbalists. This phase involved two assistants, one who was familiar with the terrain and the plants and the other a photographer.

The third activity focused on the herbalists who described all the herbs used to prepare the oils. Once all the data were collected through recordings, the researcher transcribed the text and handed it over to the translator. The final activity involved researching translation methods and determining which methods were most dominant during the process of "Translating Traditional Karonese Medical Text in Fractured Bone Setting"-Karonese as ST, and English as TT.

Presentation on techniques of translation is done prior to the identification of the methods of translation used. This was done because the method of translation was at a higher level than the translation techniques. This can only be identified if all translation techniques are known and have been identified in advance. That is why three things are definitely having an impact on the quality of translation. Quality translation requires transfer of messages accurately. Translation disclosure is in accordance with the rules, norms, and prevailing culture in the target language, and the use of aspects of language that is easily understood by the reader. Whether a translated text is easy or difficult and understood by readers has nothing to do with the field of study, but it is related to the use of aspects of language, such as the use of words, terms, and sentence construction. This research data sourced documents are interviews with four Karonese bone setters "Pertawar Penggel" and two Karonese herbalists. Karonese text is used as source text (ST), English text as target text (TT). Karo language data consist of words, phrases, clauses, and sentences. Data in the form of words and phrases are 
generally positioned as a sub-heading of Karo traditional medicine. Tangible data clauses and sentences in general are part of conversation and stories and the paraphrased sentences are to explain the names of herbs which mostly consist of parasite plants that mainly grow in the rainforests in Karo land and Aceh (protected forest Leuser).

\section{Translation From Karonese Into English}

The data were identified by applying Molina and Albir's translation techniques. The data were found by applying two (couplet) and three (triplet) translation techniques in one sentence. Of the 209-11 = 183 data sources being analyzed, there were 152 identified as decoded data by applying single techniques, 44 identified as decoded data by appling couplet translation techniques and there are 2 identified as decoded data by applying triplet translation techniques.

\section{Single Technique}

As mentioned briefly above, a single technique refers to the application of one technique alone in translating research data from Karonese into English. In this study, seven single techniques were used. They were literal, pure borrowing techniques, established equivalent, reduction or deletion, addition, transposition, and adaptation techniques.

Table 2

Single Translation Technique From ST to TT

\begin{tabular}{llll}
\hline Technique & & Single technique variety & Total \\
\hline & 1. & Literal & 66 \\
& 2 & Pure borrowing & 23 \\
Single & 3. & Established equivalent & 9 \\
& 4. & Addition & 29 \\
& 5. & Reduction/Deletion & 7 \\
& 6 & Transposition & 17 \\
& 7. & Adaptation & 1 \\
\hline
\end{tabular}

From the seven single techniques, literal techniques are most widely used (66), followed by Addition (29), pure borrowing (23), transposition (17), established equivalent (9), reduction (7), and adaptation technique (1).

\section{Literal Technique}

Literal technique translation is a technique in which the translator translates a word or an expression literally. This technique requires matching the lexical that are still tied with the source language but lexical composition that forms a phrase has already adapted the rules of the target language.

In this study the researcher identified 66 Karonese language data translated into English by applying the literal technique. They are data numbers:

\begin{tabular}{llllllllll}
\hline 28 & 62 & 66 & 70 & 86 & 111 & 134 & 144 & 146 & 148 \\
155 & 157 & 159 & 163 & 176 & 178 & 180 & 187 & 198 & 200 \\
205 & 237 & 242 & 247 & 249 & 260 & 263 & 271 & 273 & 277 \\
279 & 281 & 287 & 293 & 301 & 303 & 307 & 313 & 315 & 321 \\
323 & 325 & 327 & 331 & 333 & 335 & 337 & 339 & 341 & 343 \\
347 & 349 & 353 & 355 & 357 & 367 & 369 & 371 & 373 & 375 \\
379 & 381 & 383 & 385 & 387 & 389 & & & & \\
\hline
\end{tabular}


The followings sentence was translated from Karonese into English using the literal techniques.

\begin{tabular}{lll}
\hline Data & Karo (ST) & $\begin{array}{l}\text { English (TT) } \\
\text { To fix a broken bone, what steps do you have } \\
\text { to take to heal? }\end{array}$ \\
\hline
\end{tabular}

\section{Established Equivalent}

Translational equivalence is the similarity between a word (or expression) in one language with the translation into another language. Thus, a translation equivalent is a corresponding word or expression in another language. The following are the sample of used established equivalent techniques from Karonese into Bahasa Indonesia.

\begin{tabular}{lllllllll}
\hline 60 & 68 & 74 & 80 & 84 & 88 & 92 & 96 & 100 \\
\hline
\end{tabular}

The following are the sample of used established equivalent techniques from Karonese into English.

\begin{tabular}{|c|c|c|c|}
\hline Data & Karo (ST) & Kaciwer & English (TT) \\
\hline 60 & Kaciwer & & Cutcherry \\
\hline 68 & Serei wangi & & Citronella \\
\hline 74 & Sitelu bulung & & Tit-Berry \\
\hline 80 & Pia & & Shallot \\
\hline 84 & Lasuna & & Garlic \\
\hline 88 & Sendep sendep & & Scouring rush horsetail \\
\hline 92 & Binara & & Chinese mugwort \\
\hline 96 & Gumis kucing & & Java tea \\
\hline 100 & Tabu tabu & & Bottle gourd \\
\hline
\end{tabular}




\section{Pure Borrowing Technique}

Borrowing is a translation technique in which the translator borrows the word or phrase of the source language. The borrowing can be pure or naturalized. Pure borrowing refers to the lending source language word or phrase in full without any adjustment of pronunciation. For example, the "Kapal-kapal Garantula" in the source language text is maintained in the target language text. On the other hand, naturalized borrowing is understood as the borrowing of words or phrases followed by adjustment of pronunciation. The word "kayuputih", for example, translates into Cajeput. The second type of technique is different from the above borrowing; borrowing culture refers to the transfer of the source language into the culture of the target language.

In this study it has been identified data that is translated by pure borrowing techniques as many as 23 from ST into TT Here are the data numbers:

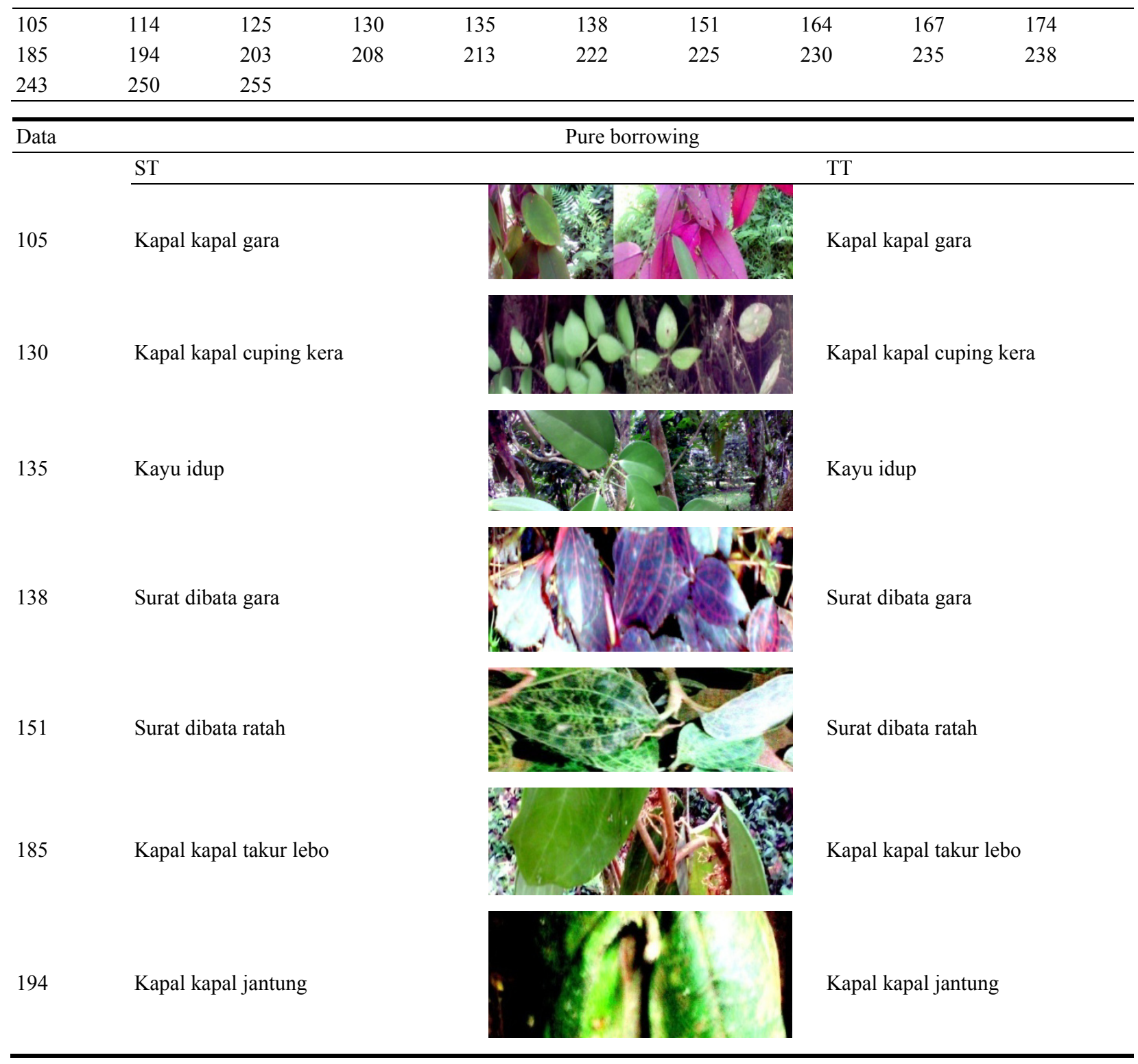




\begin{tabular}{lll}
\hline Data & ST \\
\hline $203 \quad$ Kapal kapal tawar aji & Kapal kapal tawar ipuh \\
$243 \quad$ Kapal kapal siligen negri & Kapal kapal tawar ipuh \\
\hline
\end{tabular}

\section{Addition Technique}

Additional techniques are commonly applied in translation activities. The addition in question is supplementary information that does not exist in the source sentence. The presence of additional information in the target sentence is intended to further clarify to the reader the target language. Examples: "She came late" translates into "an old lady came too late". There are 29 identified data from Karo (ST) translated into (TT) English in this study. The data numbers are:

\begin{tabular}{llllllllll}
\hline 50 & 58 & 64 & 72 & 76 & 78 & 90 & 116 & 120 & 150 \\
184 & 191 & 221 & 265 & 267 & 275 & 283 & 285 & 289 & 291 \\
295 & 297 & 299 & 305 & 319 & 345 & 359 & 365 & 391 & \\
\hline
\end{tabular}

The followings are some sample sentences from the source text which were translated into English (TT) using the addition techniques.

\begin{tabular}{lll}
\hline Data & Karo (ST) & English (TT) \\
50 & Mbue macam-macamna. & There are many different kinds of ingredients. \\
\hline
\end{tabular}

\section{Reduction/Deletion Technique}

Deletion technique is a translation technique that is realized by eliminating elements of the source language text of the target language. This removal is generally caused by a lack of grammatical equivalents. In the context of such a removal it is obligatory that a generated translation does not infringe the rules of the target language. The removal of this kind is optional. However, this deletion technique is often used as an "excuse" by translators to cover the inability to find the equivalent of the source language words in the target language. On the other hand, thorough deletion refers to removal of whole elements contained in the phrase, clause, or sentence in question. Data sources are not translated or removed from the target text.

The following is a sample sentence from the source text which was translated from Karonese (ST) into English (TT):

\begin{tabular}{lll}
\hline Data & Karo (ST) & English (TT) \\
24 & $\begin{array}{l}\text { Turikendu sitik uga mbarenda makana kam banci jadi } \\
\text { guru pertawar penggel? }\end{array}$ & Please tell me how did you become a bone setter? \\
\hline
\end{tabular}




\section{Transposition Technique}

Transposition is a translation technique by changing grammatical category. This technique is similar to the technique of shifting categories, structures and units. The verb in the source language text, for example, is converted into a noun in the target language text. Structural shift technique is commonly applied if the structure of the source language and target language are different from each other. Therefore, a shift in the structure is mandatory. The mandatory nature of the structural shift in the translation of Karonese into English is to avoid interference. The interference that may cause the grammar of the translation becomes unacceptable and incomprehensible. Here are the source data numbers:

\begin{tabular}{llllllllll}
\hline 30 & 34 & 36 & 38 & 40 & 46 & 82 & 98 & 102 & 104 \\
118 & 122 & 189 & 193 & 311 & 361 & 363 & & & \\
\hline
\end{tabular}

The following is sentence from data source translated using transposition techniques from Karonese language (ST) translated into English (TT).

\begin{tabular}{lll}
\hline Data & Karo (ST) & English (TT) \\
30 & Tang tangna kuperiksa kondisi tulan sipenggel e. & First, I check the condition of the fractured bone. \\
\hline
\end{tabular}

\section{Adaptation Technique}

The following sentence is from the source data translated using Adaptation techniques from Karonese translated into English.

\begin{tabular}{lll}
\hline Data & Karo (ST) & English (TT) \\
26 & E Enggo factor keturunen. & It runs in the family. \\
\hline
\end{tabular}

\section{Couplets Translation Technique}

As mentioned previously, in addition to a single technique there are also found couplet techniques, which are a combination between the two translations techniques applied in determining the equivalent in the target language. The combination of two of the translation techniques : literal technique + pure borrowing technique, literal technique + calque technique, literal + established equivalent technique, addition + pure borrowing technique, addition + transposition technique, deletion + pure borrowing technique, adaptation + pure borrowing technique, and transposition + pure borrowing technique.

Table 3

Couplet Translation Technique From ST to TT

\begin{tabular}{llll}
\hline Technique & & Couplet technique variety & Total \\
\hline & 1 & Literal + Pure borrowing & 30 \\
& 2 & Addition + Pure borrowing & 4 \\
Couplet & 3 & Addition + Transposition & 3 \\
& 4 & Deletion + Pure borrowing & 2 \\
& 5 & Adaptation + Pure borrowing & 2 \\
& 6 & Literal + Calque & 1 \\
& 7 & Transposition + Pure borrowing & 1 \\
\hline
\end{tabular}


Table 3 above shows that in eight variants couplet techniques, a blend of literal technical and pure borrowing technique is applied in a dominant position (30), followed by a mix of addition and pure borrowing (4), addition technique and transposition (3). The frequency use of the other techniques variant is very low. All the five variant couplet techniques will be described below.

\section{Literal + Pure Borrowing Technique}

There were 30 data translated with couplet techniques with a variation of literal and pure borrowing technique in this study including the following numbers:

\begin{tabular}{llllllllll}
\hline 42 & 52 & 56 & 107 & 124 & 127 & 129 & 132 & 137 & 140 \\
142 & 153 & 161 & 166 & 169 & 171 & 173 & 202 & 207 & 210 \\
212 & 217 & 229 & 234 & 240 & 245 & 257 & 259 & 317 & 395 \\
\hline
\end{tabular}

The data included in this category are basically dominated by the application of the literal technique shown by the wording adjustments based on the rules that apply in the target language. This technique requires matching the lexical that are still tied with the source language but the lexical composition that forms a phrase has already adapted the rules of the target language. It is shown in the following examples:

The following sentence is from the source data that has been translated from Karonese (ST) into English (TT) using literal + pure borrowing technique.

\begin{tabular}{lll}
\hline Data & Karo (ST) & English (TT) \\
42 & $\begin{array}{l}\text { Encage Iberekenka tawar ipanna gelah mempercepat } \\
\text { pergegeh tulan. }\end{array}$ & $\begin{array}{l}\text { Then "tawar" is given to be taken in order to accelerate the } \\
\text { strengthening of bones. }\end{array}$ \\
\hline
\end{tabular}

\section{Literal Technique + Calque}

A combination of literal technique and calque happened on research data below. Sentence structure adjustment in translation is understood as an attempt to produce a translation that can be acceptable to the target language.

Meanwhile, the interference structure of the source language in the target language as the hallmark of calque technique arise as a result of the inability of translators in finding the exact equivalent in the target language. Therefore, the translator tends to not only perform structural interference but also lexical. Intended data are data numbered 309.

\begin{tabular}{|c|c|c|}
\hline Data & Karo $(\mathrm{ST})$ & English (TT) \\
\hline 309 & $\begin{array}{l}\text { Kenca bahan pulung kerina emaka proses erbahan } \\
\text { tambar mulai imulai salu mbaca bacaka: } \\
\text { Bismillahirhamanirrahim. }\end{array}$ & $\begin{array}{l}\text { After all materials are gathered, the process of making the oil } \\
\text { starts by saying Bismillahirahmanirrahim. }\end{array}$ \\
\hline
\end{tabular}

\section{Literal + Established Equivalent Technique}

This study also identified one target data generated through the application of a mixture of literal technique and established equivalent technique. Here is the data translated from Karonese into English using literal and established technique:

\begin{tabular}{lll}
\hline Data & Karo (ST) & \multicolumn{1}{c}{ English (TT) } \\
54 & Hasil wawancara ras dua kalak ahli bulung-bulung \\
kerangen, pasangen dilakina ras diberuna I Pancur & $\begin{array}{l}\text { The interviews result with two herbalists, a couple from Pancur } \\
\text { Batu. }\end{array}$ \\
\hline
\end{tabular}




\section{Addition + Pure Borrowing Technique}

This study has identified a variant couplet techniques which are a combination of addition and pure borrowing techniques. The data are number 224, 254, 44, and 196. They have been translated from Karonese into English.

\begin{tabular}{lll}
\hline Data & Karo (ST) & English (TT) \\
44 & Kam ngei erbansa Minak, tawar ras kuning e? & Did you make the medicational oil, tawar and kuning? \\
\hline
\end{tabular}

\section{Addition + Transposition Technique}

Additional techniques are commonly applied in translation activities. The addition in question is additional information that basically does not exist in the source sentence. The presence of additional information in the target sentence is intended to further clarify the concept that the original author is trying to convey to reader the target. Example: "She came late" translates into "an old lady came too late". Transposition is a translation technique by changing grammatical categories. This technique is similar to the technique of shifting categories, structures, and units.

The following is a sentence from the source data that has been translated from Karonese into English using Addition and Transposition Technique.

\begin{tabular}{lll}
\hline Data & Cakap Karo (ST) & English (TT) \\
219 & Gedang bulungna seh $6 \mathrm{~cm}$, belangna seh $4 \mathrm{~cm}$. & The leaf can reach $6 \mathrm{~cm}$ long and $4 \mathrm{~cm}$ wide. \\
\hline
\end{tabular}

\section{Deletion+ Pure Borrowing}

The following is sentence from the source data that has been translated from Karonese language into English using deletion and pure borrowing techniques.

\begin{tabular}{lll}
\hline Data & Cakap Karo (ST) & English (TT) \\
215 & $\begin{array}{l}\text { Lancing kerangenturah bas taneh kerangen } \\
\text { berhawa mbergeh. }\end{array}$ & Lancing Kerangen grows in temperate rain forest. \\
\hline
\end{tabular}

\section{Adaptation + Pure Borrowing Technique}

The following sentence is from the source data that has been translated from Karonese into English using adaptation and pure borrowing techniques.

\begin{tabular}{lll}
\hline Data & Karo (ST) & English (TT) \\
& Siang-siang torah itepi kerangen, gedang batangna & Siang-Siang is an herbaceous plant that grows in the \\
227 & $\begin{array}{l}\text { lebih kurang sada meter ganjangna, rupana merah } \\
\text { jambu. Ganjang batangna lebih kurang sada meter. }\end{array}$ & temperate rain forests and has pink-colored flowers. The \\
& height the can reach approximately one meter.
\end{tabular}

\section{Transposition + Pure Borrowing Technique}

The following sentence is from the source data that has been translated from Karonese Language into English using Transposition and pure borrowing techniques.

\begin{tabular}{lll}
\hline Data & Karo (ST) \\
& $\begin{array}{l}\text { Binara ibahan kalak Karo gelarna perban bungana } \\
\text { mbentar melala, adi kena las matwari rupana } \\
\text { erbinar. E maka ban kalak Karo gelarna BINARA. } \\
\text { Erbinar ertina ersinar. }\end{array}$ & $\begin{array}{l}\text { English (TT) } \\
\text { The Karonese call this plant Binara because it has small white } \\
\text { in English. }\end{array}$ \\
\hline
\end{tabular}




\section{Triplet Translation Technique}

Triplet translation technique refers to a combination of three translation techniques applied in translating a phrase or a sentence. In this study identified there are two variants of the triplet technique.

Table 4

Triplet Translation Technique From ST to TT

\begin{tabular}{llll}
\hline Technique & Triplet translation technique & Total \\
\hline \multirow{2}{*}{ Triplet } & 1 & Calque + Pure borrowing + Literal & 1 \\
& 2 & Amplification + Pure borrowing + Additional & 1 \\
& Total & 2 \\
\hline
\end{tabular}

\section{Literal + Addition + Pure Borrowing Technique}

Two data have been identified in this study using a variant triplet technique which is a combination of literal, addition, and pure borrowing techniques. The data number is 393 . The data have been translated from Karonese language into English.

\begin{tabular}{|c|c|c|}
\hline Data & Cakap Karo (ST) & English (TT) \\
\hline 393 & $\begin{array}{l}\text { Mantra fungsina gelah pasien percaya diri jadi } \\
\text { tambah gegehna emaka pinakit lampas madaan. }\end{array}$ & $\begin{array}{l}\text { The function of the Mantra had been only to reassure the } \\
\text { client. The purpose had been to make them confident that } \\
\text { he/she would be strong and had speedy recovery. }\end{array}$ \\
\hline
\end{tabular}

\section{Literal + Calque + Pure Borrowing Technique}

Structural differences between Karonese, the source language (ST) and English as the target language (TT) required the application of literal + pure borrowing + deletion technique. One data has been identified in this study using a variation of triplet techniques which is a combination of literal, calque, and reduction techniques. The following data have been identified:

\begin{tabular}{lll}
\hline Data & Cakap Karo (ST) & English (TT) \\
48 & $\begin{array}{l}\text { Ramun kai saja iprosesndu jadi minak pengalun, tawar } \\
\text { ras kuning? }\end{array}$ & minakpenalun, tawar, and kuning? \\
\hline
\end{tabular}

\section{Discussion of Research Findings}

According to the calculations, the total number of data source included in this study is 183 . There are 152 data that have been translated through single techniques; 44 data were translated using couplet translation techniques and two of the data were translated by triplet translation techniques. This is related to the nature of translation techniques which is directed to the smallest level. In other words, the translation techniques generally applied on lingual unit that is under the level of a sentence or clause. The techniques that were applied to the translation of a sentence or a clause are varied because a sentence or a clause is built from lingual units that are at the smallest level.

In analyzing frequency of translation methods, the literal technique was most commonly implemented (99), followed by pure borrowing (62), addition (38), transposition (21), established equivalent (10), deletion (9) adaptation (3), and calque (2).

The literal technique and pure borrowing technique were implemented most frequently because of the need to change the wording or adjust the wording in the target language (TT). If such adjustments were not made, then the resulting translation would violate the rules that apply in the target language, or in the source 
language (ST). Without such adjustments, readers would have difficulty in understanding the translation. In addition, the herbs derived from rain forests in Leuser and in Deli Serdang were in Karonese with no equivalent in English.

For example: "Surat Dibata", has no equivalent in the Malay language or Indonesian language, then translated out of context will become "Suratdari Tuhan" in Indonesian, and "Letters From God" in English. Similarly, the term Tapak Raja Sulaiman in Karonese language is translated in Indonesian as "King Salomon's Footprints". There is also an herb called "Sirang-Sirang" in Karonese which means "Selamat Tinggal" or "Selamat Jalan" in Indonesian and it means "Farewel" or "Good Bye" in English. Translating the names of specific herbs would be very confusing for readers who do not understand the target language and could possibly lead to misunderstandings. Therefore, the names of these herbs should remain in their original forms. Using "pure borrowing" translation technique is the only solution as this will not distract the target language readers and allow for better comprehension of the text.

In the light of legibility, providing additional explanations regarding technical terms would be very disturbing for the reader to understand the contents of a translation. Therefore, additional information should be placed in an appendix.

\section{Conclusion and Suggestions}

\section{Conclusion}

Individual adaptation and adjustment to the changing global and social environment is the key to success. However, before adapting to the globalization era, one needs to understand one's own cultural values and beliefs in order to be able to adapt to other cultures. Indonesian children should therefore be aware of and understand the cultures and the values and beliefs that their ancestors held dear.

To keep a language alive, it is partly the duty of the speakers to help preserve it. Other strategies such as reviewing, recording and studying the tradition of hundreds of ethnicities in Indonesia may also help to preserve indigenous languages and cultures. For example, through this study concerning the traditions of bone setters in North Sumatra, one aspect of Karonese tradition and culture will be preserved in some way. Healing fractured bones through alternative treatments has long been known by the people of North Sumatra but this knowledge may become extinct without means of preservation. By recording and translating methodologies provided by traditional Karonese bone setters and herbalists, this study has offered opportunities for keeping such practices alive. Furthermore, translating Karonese medical practices into English may benefit Karonese youth who have lived to larger towns and no longer speak Karonese. Reading this study in English can help them learn about their traditional medical care and possibly lead to regaining a sense of pride in their ethnicity.

It was stated previously that this study aims to formulate translation techniques applied in the translation of traditional Karonese medical practices in healing fractured bones from Karonese into English. This study has proven that implementing the Pure Borrowing Technique and the Literal Technique is the most effective way of translating Karonese medical terms in the field of traditional medicine. Therefore, it is not only feasible but also necessary so that the original Karonese medical terms can be faithfully preserved in the translation. The methods of translation which dominated were word-for word, literal, faithful, and semantic translation methods. The translation of "Traditional Karonese Medical Text in Fractured Bone Setting" by the translator, Dr. Matius Sembiring, resulted as a source language emphasis. The translation using the most literal equivalence that is closely attached to the terms of the source language is not only feasible, but also desirable, even necessary, so that 
the original Karonese terms can be faithfully preserved in the translation. It also illustrates a comprehensive and accurate transmission of knowledge from one culture to another.

\section{Suggestions}

Suggestions for other researchers in translation raise the issue of traditional medicine as credible subject matter. This is the first study done on the level of dissertation at the University of North Sumatra. This study tries to raise the issue of traditional medicine as a subject. This research may encourage the Indonesian government to support traditional medications available for bone setting and provide subsidies to support for clinics that exist in Indonesia. Knowing there are so many herbs available and are in use, it might be a good idea to build a herbarium in the campus of University of North Sumatra and process and produce the herbs to all over Indonesia as well as the International Community including the World Health Organization.

\section{References}

Arie, M. J. H., Joosten, H., Wegdam, H. H. J., \& Van Der Geest, S. (2007). Fracture treatment by bonesetters in central Ghana: Patients explain their choices and experiences. Tropical Medicine and International Health, 12(4), 564-574.

Baker, M. (1992). In other words: A coursebook on translation. London: Sage Publication.

Bell, R. T. (1991). Translation and translating: Theory and practice. London: Longman.

Bell, R. T. (1998). Psychological/cognitive approaches. In M. Baker (Ed.), Routledge encyclopedia of translation studies. London, New York: Routledge.

Catford, J. C. (1965). A linguistic theory of translation: An essay in applied linguistics. London: Oxford University.

Ediriweeraa, E. R. H. S. S., \& Bgreru, D. D. (2009). Traditional medical practices of Sri Lanka in orthopaedic treatment institute of indigenous medicine (University of Colombo, Rajagiriya, Sri Lanka).

Hatim, B., \& Munday, J. (2004). Translation: An advance resource book. London and New York: Routledge.

Haviland, W. A., Fedorak, S. A., Crawford, G. W., Lee, R. B., \& Haviland, W. A. (2005). Cultural anthropology. Toronto: Nelson.

Hervey, S., Higgins, I., \& Haywood, L. M. (1995). Thinking Spanish translation: A course in translation method: Spanish into English. London and New York: Routledge.

Kaelan, M.S., Drs. (1988). Filsafat Bahasa (masalah dan Perkembangannya) (Language philosophy (Development and problems)). Yogyakarta: Paradigma.

Katz, J. J. (1988). The philosophy of language (Department of Humanities and Reasearch of Library of Electronics, Massachusets Institute of Technology).

Larson, M. L. (1984). Meaning-based translation: A guide to cross-language equivalence. Boston: University Press of America.

Mabberley, D. J. (2008). Mabberley's plant-book (3rd ed., pp. vii-xviii, 1-1021). Cambridge: Cambridge University Press.

Miles, M. B., \& Huberman, A. M. (1984). Qualitative data analysi: An expanded sourcebook. California: SAGE Publications, Inc..

Molina, L. M., \& Albir, A. H. (2002). Translation techniques revisited: A dynamic and functionalist approach (Universidad Autònoma de Barcelona, Barcelona, Spain).

Muchizar, M. (2010). Tematisasi dalam translasi dwi bahasa; Teks Bahasa Inggris ke Bahasa Indonesia (Thematization in bilingual translation; English text into Indonesian text). Medan: USU Press.

Munday, J. (2008). Introducing translation studies: Theories and application. New York: Routledge.

Napitupulu, J. (2012). Upacara Ritual Dan Pengobatan Tradisional Karo (Ritual ceremony and Karonese traditional medicine).

Retrieved from http://radiansyahhadichandra.blogspot.com/2012/02/perkembangan-tumbuhan.html

Newmark, P. (1982). Approaches to translation. Oxford: Pergamom Press.

Newmark, P. (1988). Textbook of translation. Oxford: Pergamon Press.

Newmark, P. (1991). About translation. Clevedon: Multilingual Matters.

Newmark, P. (1993). Paragraph on translation (p. 19). Clevedon: Multilingual Matters Ltd..

Nida, E. A., \& Taber, C. R. (1982). Helps for translator. In The theory and practice of translation. New York: United Bible Society. 
Nuh, M. (2013). Ministry of Education of Republic of Indonesia until 2013. Retrieved from http://www.antaranews.com/berita/351761/pelajaran-bahasa-daerah-tetap-ada

Owumi, B. E, Taiwo, P. A., \& Olorunnisola, A. S. (2013). Utilization of traditional bone-setters in the treatment of bone fracture in Ibadan North Local Government. International Journal of Humanities and Social Science Invention, 2(5), 47-57.

PituSuryo. (2013). Rahasia ilmu ghoib (The secret of occult). Retrieved from http://padepokansuryopitu.blogspot.com/2013/01/ilmu-batak.html

Purba, S. L. (2013). Perubahan paradigm dalam menyikapi globalisasi social budaya untuk kejaya an Indonesia (A paradigm shift in addressing the socio-cultural of globalization to the glory of Indonesia). Retrieved from http://maspurba.wordpress.com/2013/05/16/perubahan-paradigma-dalam-menyikapi-globalisasi-sosial-budaya-untuk-kejayaan-i ndonesia/

Quinn, G. (2001). The learner's dictionary of today's Indonesian. Sydney: Allen \& Unwin.

Robinson, D. H. (1997). Becoming a translator: An introduction to the theory and practice of translation. London: Routledge.

Sembiring, M. (2013). Translating Rebu in Karonese society into English (Dissertation, Faculty of Cultural Science, University of Sumatera Utara).

Silalahi, R. (2009). Dampak Teknik, Metode, dan Ideologi Penerjemahan Pada Kwalitas Terjemahan Teks Medical-Surgical Nursing dalamBahasa Indonesia (The impact of the translation techniques, methods, and ideologies on the quality of the translated text medical-surgical nursing in Bahasa Indonesia) (Dissertation, Sekolah Pascasarjana Universitas Sumatera Utara, Medan).

Simalem, T. K. (2013). Jenis-Jenis Obat-Obatan Tradisional Suku Karo (Different kinds of traditional Karonese medicine). Retrieved from http://merga-silima.blogspot.com/2013/07/jenis-jenis-obat-obatan-tradisional.html

Toshikhane, H. D., \& Sangetta, H. J. (2009). Fracture management in traditional Indian medicine. The Pacific Journal of Science and Technology, 10(1).

Udosen A. M. (2006). Role of traditional bone setters in Africa: Experience in Calabar (Nigeria Department of Surgery, University of Calabar \& University of Calabar Teaching Hospital, Calabar, Nigeria).

Udosen, A. M. (2006). Role of traditional bone setters in Africa: Experience in Calabar. Nigeria Annals of African Medicine, 5(4), 170-173.

Venuti, L. (1998). The scandals of translation: Towards an ethics of difference. London: Routledge.

WHO traditional medicine strategy: 2014-2023. (2013). WHO, Geneva.

Wiart, C. (2006). Medicinal plants of Asia and the Pacific (p. 300). USA: CRC Press.

Wiseman, N. A. R. (2000). Translation of Chinese medical terms: A source-oriented approach in complementary health studies (Doctor of Philosophy in Complementary Health Studies, University of Exeter).

Zohre Owji, M. A. (2013). Translation strategies: A review and comparison of theories. Retrieved July 23, 2014 from $\mathrm{http}: / /$ translationjournal.net/journal/63theory.htm 